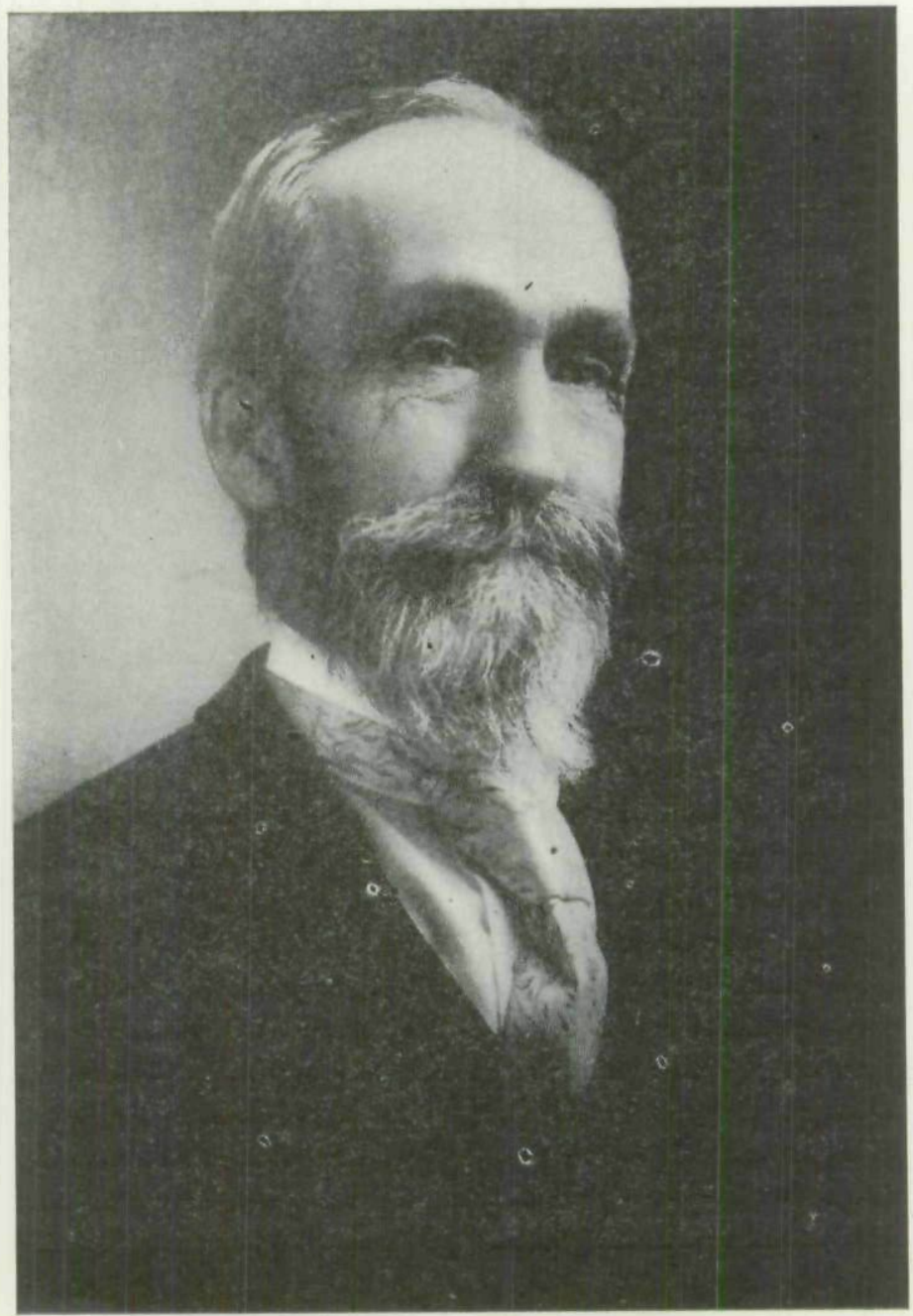

COL. GUSTAVUS BENSON BRACKETT

From a photograph in the office of the Secretary of Horticulture. Dr. Robert S. Herrick, Secretary, succeeding to that office Hon. Wesley Greene, related to the editor of the ANNALs, that as Mr. Greene was retiring from the related to the editor of the Aaid: "Now, don't let anyone take this pioture down. It is of one of the greatest Iowa horticulturists-Col. G. B. Brackett." 


\title{
GUSTAVUS BENSON BRACKETT
}

\author{
By David C. Motw
}

Not all fame is won in leading armed hosts against our country's enemies, nor in the forum of debate in the halls of Congress; sometimes it is won in the quietude of scientific investigation when nature's secrets are discovered and made to serve the wants of men. Gustavus B. Brackett turned his talents to account in aiding the pioneers of Iowa to find the fruits best adapted to the soil and seasons of the embryo state, and deserves a place of remembrance among her illustrious men.

Gustavus Benson Brackett was born at Unity, Waldo County, Maine, March 24, 1827. His parents were Reuben and Elizabeth S. Brackett. ${ }^{1}$ The family removed to Cincinnati, Ohio, in 1837, and to Denmark, Lee County, Iowa, in 1841, where Reuben Brackett established a nursery, and where he remained until the end of his life. ${ }^{2}$ Reuben Brackett was one of the Board of Trustees of Denmark Academy on its incorporation in $1843,{ }^{3}$ and was a member of the Board of Trustees and president of the officers of the corporation of the Academy through several years ending with 1857, as shown by the catalogues of the school. This is evidence of his standing in the community. The son, Gustavus B., obtained his education in public schools in Cincinnati, and in Denmark Academy, and then joined with his father in the nursery business. On September 15, 1861, he was appointed first lieutenant in Company I, Engineer Regiment of the West, was mustered October 31, 1861, and was promoted to captain July 5, 1862..$^{4}$ He was chief of engineers under General Grant for a while, and was topographical engineer with General Sherman in his famous march to the sea. ${ }^{5}$ At the close of the war he returned to Denmark and to the nursery business.

${ }^{1}$ Who's Who in Amer., Vol. VII, 1912-13, p. 224.

Biographical sketch of Col. G. B. Brackett in Report of the Iovea Slate Horticultural Society, Vol. 50, 1915, p. 184 .

3istory of Lee County, Iouca, Western Historical Company, Chicago, 1879, p. 672 .

${ }^{4}$ Roster of Iowa Soldiers. Vol. VI, p. 149.

sBiographical sketch in Horticultural Report, loc. cit. 
After the war he was for a time a lieutenant colonel in the Iowa Militia. ${ }^{6}$

After finishing school at the Denmark Academy, with the exception of some four years in the army, he gave his energies to the nursery business which his father had established. On June 26,1866 , there was formed at Iowa City the Iowa State Horticultural Society, an organization destined to greatly influence the career of Colonel Brackett. The first officers were Dr. James Weed of Muscatine, president; D. W. Kauffman of Des Moines, vice president; Mark Miller of Des Moines, secretary; and David Leonard of Burlington, treasurer. On January 9, 1867, the society held its first meeting for public discussion in the Court House in Des Moines. D. W. Kauffman was elected president and W. W. Beebe of Dubuque, secretary for the following year. On January 7, 1868, they met again in Des Moines and J. B. Grinnell became president and Dudley W. Adams of Allamakee County, secretary. At that time a constitution was adopted. ${ }^{7}$

Colonel Brackett about this time became a member of the society. In a letter of greeting written for the society for its meeting in 1896 he says he was a member of the organization from its inception. At its meeting at Keokuk September 14, 1869, is the first one in which we find him taking part. There with others of a committee he signed a memorial to the General Assembly asking for an appropriation to be made of $\$ 2,000$ for the following biennium for horticultural purposes. He prepared and read an article on "Pears in Southern Iowa," and was appointed chairman of a committee to report on pears, plums, cherries and peaches, which was one of eight committees appointed to make investigations and report on different fruits best to be raised in Iowa. ${ }^{8}$

At this time Colonel Brackett was forty-two years old and was in his prime, a man of vigor, and we find him entering into the activities of the society with enthusiasm. At its meeting held at Keokuk January 11, 1871, he became a member of the Board of Directors of the society, and at that meeting and at the following one he made reports concerning the conditions and results of fruit raising in his district.

"Who's Who in Amer., loc. cit.

7First Annual Report Ia. State Hort. Soc., 1867, pp. 114-16.

8 Report Ia. State Hort. Soc., 1869. 
January 21, 1873, the meeting was held in Davenport. Suel Foster was president. We find Colonel Brackett taking part in discussions. Among the membership were some of the leading fruit growers and nurserymen in the new state, such as J. L. Budd of Shellsburg, C. L. Watrous of Des Moines, D. W. Adams of Waukon, and G. P. Wood of Springdale. The discussions developed the experiences of the members with different varieties of apples, pears, grapes, etc., and their conclusions as to those varieties most suitable to the new state. At the close of this meeting Suel Foster declined re-election as president, "hoping the society would select a younger man," whereupon "G. B. Brackett of Lee County was elected president, and the choice made unanimous."

The meeting of the Horticultural Society of January 20-22, 1874, was held at Iowa City. Colonel Brackett delivered the annual address as president of the society, speaking in part as follows :

You have left your cares and toils-your pleasant homes-for a while and come from distant parts of the state to meet each other in social intercourse, to exchange the genial smile and the hearty fraternal handshake. You have come to contribute of your wisdom and experience to the great fund of human knowledge. You meet here co-laborers in a noble vocation-a band of "Nature's noblemen," to compare notes and experiences, to counsel and advise, to learn from each other, to the mutual benefit of all. The art of horticulture, coeval with the very existence of man, is one of the noblest and most interesting studies in which the student can engage. In it he "looks through nature up to nature's God." Every tree, shrub and plant, every leaf and flower, points upward to the great first cause of things. . . . . Its influence is refining to the character; it tends to promote social happiness and public morality, and with its kindred sciences which embrace geology, meteorology, entomology, botany, agricultural chemistry, and vegetable physiology, it opens a field of investigation as wide as the universe, and he who enters upon it will find that it is not the work of a day. .... It is not for him who has enjoyed the fruits which it has taken hundreds of years to perfect, to refrain from the good work that is to increase the happiness of countless millions that are to come after him.

It seems to me that much of our time at these meetings should be devoted to the discussion of fruits. Addresses, essays, and theoretical papers are proper in their place but should not occupy too much of our time. .... Stern facts are the things with which we should deal.

Ibid., 1872, p. 83. 
Practical experience is worth more than all else, and I hope you will all bear in mind the importance of your improving every opportunity to impart your knowledge to others, and engage freely in the discussions.

I wish to direct your attention to forestry, a branch of our science that is of greater importance, perhaps, than all others just at this time, and especially to the dwellers on the broad and treeless prairies of the west. To him who grows corn for fuel, the question of how to grow timber instead is of the deepest importance. Fruits and flowers he can do without, but not fuel or timber. Iron to a certain extent is taking the place of wood. But for a thousand different uses there has nothing been found to supply its place. To us who are accustomed to live in a well timbered country, this subject may not appear of such vast importance, but let us consider that our forests are fast disappearing before the woodman's axe, and that their total destruction is only a question of time, unless some effort is made to supply the waste. ${ }^{10}$

Before the close of the meeting Colonel Brackett was re-elected president. The ninth annual meeting of the socieity was held at Burlington January 19-21, 1875. General Augustus C. Dodge made the address of welcome to the society. Colonel Brackett's annual address as president was again replete with eloquence and wisdom. From the address we quote:

We come with hearts of love for the work in which we are engaged, with fraternal feelings for our co-workers who gather here with us from all parts of the state, and to those from other states we extend the hand of fellowship and tender you a cordial welcome, and invite you to participate in our deliberations.

President Brackett refers to the death of Mark Miller of Des Moines which occurred the previous April, and said further that Mr. Miller had been a helpful member from the beginning of the society. He had been an agricultural journalist many years, and was also a practical horticulturist and pomologist. He had charge of an exhibition of Iowa fruits at the American Pomological Society held at Philadelphia two years previous and bore off the Wilder Medal for the best collection of apples.

The society at this time was receiving $\$ 1,000$ annually from the state "for the promotion and encouragement of horticulture." The society was making plans to make an exhibit of fruits at the Centennial Exposition at Philadelphia the next year. Before adjournment Colonel Brackett was elected president for the third consecutive year.

\footnotetext{
10Ibid., 1873, pp. 23-27.
} 
The tenth annual meeting of the society was held in Des Moines January 18-20, 1876, President Brackett in the chair. $\mathrm{By}$ request of the president the session was opened with prayer by Rev. John A. Nash. The address of welcome was made by Mayor A. Newton.

One subject considerably discussed at this session was the lack of interest the new State Agricultural College at Ames was taking in horticulture. On this subject Suel Foster said during the discussion of the subject:

It is unfortunately true that horticulture, so far in the history of our college, has been almost ignored. The cattle department, the farm department, physies, civil engineering, and even military tactics must have full scope and allowances, but the one department most in need of aid in the way of an experimental station must get along under every inconvenience. Not a propogating house, not a room suitable for indoor horticultural work, or instruction, and not even a cellar for the keeping of roots and plants has yet been provided. Not a fourth-class nurseryman in the state but has superior advantages for successful work in this line over our State Agricultural College.11

A committee was appointed to present their cause to the College Board with Mr. Foster as chairman. Preparations went forward for an exhibit of fruits of the state at the approaching Centennial Exposition at Philadelphia. At the election of officers for the coming year Colonel Brackett was elected president for the fourth consecutive year. At a meeting of the Board of Directors of the society President Brackett was appointed as the representative of the society at the exposition at Philadelphia with full control and management of the exhibit of fruits and woods of the society, and his reasonable expenses connected with the service to be paid from the funds of the society. ${ }^{12}$

The eleventh annual meeting was held at Oskaloosa January 16-19, 1877, President Brackett presiding. Secretary Joseph L. Budd said in his report to the society:

The exhibit of our society at the great Philadelphia Exposition of casts, fruits, wood specimens, etc., attracted world-wide attention and admiration. . . . . President Brackett, for his persistent labors from the commencement of our effort to make a creditable display, to the termination of the great show, deserves thanks such as words can hardly express. ${ }^{13}$

\footnotetext{
11 Ibid., 1875, p. 178.

12Ibid., 1875, p. 266 .

18lbid., 1876, p. 26.
} 
Mr. Brackett made a report to the meeting in which he stated the Executive Council was authorized to make an exhibit of fruits at the exposition, but they made him one of the managers, so their efforts harmonized, Mr. Brackett acting for the state as well as for the society. In April he with his helpers placed under glass shades 1,000 facsimiles representing 300 varieties of fruits, all grown in Iowa in 1875. This was an exhibition no other state attempted to make, and

Throughout the entire season it was a great center of attraction to the thousands who visited the exposition. .... So true to nature were these models that they were generally taken to be genuine fruit, and in many instances the sense of sight alone would not satisfy the curious observer, they must lift the shades to see if they could not catch the aroma, or handle them before they would be convinced they were but imitations of real fruit.

By September Colonel Brackett and his assistants were able to receive from their membership in Iowa fresh fruit sent in refrigerator cars and put on an exhibit of fresh fruits the largest of any state - 342 varieties of apples, 50 varieties of pears, and several varieties of plums, quinces and grapes. With regard to this Colonel Brackett says, "We have shown to the world that in addiiton to the numerous and varied productions of our noble state, we can produce as fair fruit as nature ever painted with its golden hues."

They also put on an exhibit of 160 varieties of native and cultivated woods. ${ }^{14}$

Colonel Brackett declined to accept the presidency of the society for another year, saying he so far neglected his private business the previous year because of the Philadelphia Centennial Exposition, that for pecuniary reasons he wished to be excused. He was, however, by vote of the society made an honorary life member along with J. B. Grinnell, James Smith of Des Moines, and Suel Foster of Muscatine.

The twelfth annual meeting of the society was held in Des Moines January 15-18, 1878, H. W. Lathrop of Iowa City presiding. At this meeting Colonel Brackett reported on behalf of himself and John N. Dixon of Mahaska County, who were appointed delegates of the society to attend the American Pomological Society to be held at Baltimore in September, 1877, that

\footnotetext{
${ }_{14}$ From Col. Brackett's report in Report Ia. State Hort. Soc., 1876, pp. 123-32.
} 
Mr. Dixon being unable to. attend, he went alone. About 100 delegates were present, many of them being leading pomologists of the country. At the sessions discussions were had concerning the improved processes of canning and of drying fruit, and of exporting fresh fruit, especially apples, to England and other European countries.

In 1878 Colonel Brackett was appointed an honorary commissioner to the International Industrial Exposition at Paris, France. The governor of each state nominated two honorary commissioners and the president of the United States appointed them. Colonel Brackett and Alfred Hebard were thus appointed from Iowa, but we find no evidence that they attended the exposition.

The thirteenth annual meeting of the society was held at Marshalltown January 21-24, 1879. Colonel Brackett it seems did not attend, but contributed a letter to the director of his district concerning the condition of the fruit erop in his county, showing his willingness to do whatever was assigned to him to do, whether it was one of high honor, or one of the necessary smaller duties of members. There is also a report of the Committee on Nomenclature, signed by himself, calling attention to the troubles resulting from carelessness of nurserymen in not furnishing trees true to name.

The fourteenth annual meeting met at Des Moines January 20-23, 1880. C. L. Watrous of Des Moines was president and J. L. Budd of Ames, secretary. President Watrous said in his address :

This society, chartered and pensioned by the state, and charged with labors of the highest importance to the material development of the state, should clearly-unless it proved itself unworthy-have a home allowed it in the House of the State. The magnificent collection of fruit casts and woods which so worthily represented the fruits and forests of this state at the Centennial are now liable to damage and decay, without a resting place. They deserve well of the people of this state, and should at least have one room allowed them out of the multitude to be in the great marble pile upon yonder hill top. ${ }^{15}$

The new Capitol was slowly nearing completion and they were casting envious eyes toward it. Four more years were to elapse before its formal dedication. The society adopted a resolution appointing a committee, C. L. Watrous, A. H. Lawrence, Suel

\footnotetext{
${ }^{15}$ Report Ia. State Hort. Soc., 1879, p. 116.
} 
Foster, Al Swalm, and G. B. Brackett, to ask the legislature to assign to the society room in the new building for the use, library, and museum of this society. ${ }^{16}$

The meeting of January 18-21, 1881, was held at Cedar Falls. Colonel Brackett presented a paper on "Useful and Noxious Birds," showing his close observation of bird habits, anad indicating his love of nature. We quote a portion of it:

We are aware that we are departing from the old beaten track when, instead of calling the birds our friends without any distinction, we propose to arraign a part of them as our enemies. To claim without discrimination that the birds are our friends, is as unjust and false as it is to say that insects are our enemies, for in the insect world we have our friends in the predacious and parasitic tribes, who aid in destroying the noxious insects, just as truly as we have among the birds. It is therefore highly important that we study the habits of our feathered songsters, that we may know which are our friends and which are our enemies. We should study their feeding habits, for in this way we can distinguish friend from foe. As a general rule, the insectivorous birds are our friends, such as the little house-wren, always active in destroying thousands of insects every day, and the blue-bird, which is never known to eat anything but insects.

It is among the omnivorous tribes that we find those little pests that are so annoying to the fruit grower, and we will mention a few of the most injurious with whose services we are perfectly willing to dispense, believing that all their good qualities do not balance their evil propensities. And first on the list we will mention that miserable sneak thief, the brown thrush. I should have said grape thief, for they are very destructive to this our choicest fruit. From the time that our earliest grapes begin to color, they are on hand, from early in the morning till late at night, thrusting their bill into the best grapes of each cluster and sucking out the juice, leaving nothing but the skin and pulp; so he goes, from bunch to bunch, spoiling every one he touches. If he would eat up clean as he goes, we would be willing to allow him three square meals a day; but, since he will not be decent, we say shoot him.

The robin comes next and is nearly or quite as bad as the thrush on grapes, while he is very destructive to the early fruits, taking the cherries and raspberries as soon as they begin to ripen with as much complacency as though he was the sole proprietor of the domain. He is so familiar that he builds his nest where it will be most convenient for him to help himself and family to the choicest fruits. The catbird, though not quite so greedy, helps himself freely to all small fruits, and when you dispute his right to do so, will fly into a tree close by and set up his saucy squall at you, and like the thrush and robin, not to be

16Ibid., 1879, p. 264. 
frightened off by bits of glittering tin or old hats and clothes hung in the trees to scare him away.

The orioles are very destructive to grapes, and are very sly in their thievish operations, seeming to have a consciousness of their guilt and very suddenly take to their wings when detected in their nefarious operations, so that it is quite difficult to dispatch them, but as they are not as numerous as some of the above mentioned birds, we can bear with them in their wily tricks much better than with some of the others. ${ }^{17}$

Colonel Brackett also read a paper at the same meeting on "Mistakes on Pear Growing," and another on "Nomenclature." He attended the annual meetings of the society quite regularly, producing papers of value. They show the scientist, the experimenter, the practical nurseryman and fruit grower, as well as the idealist. He had command of a good vocabulary and a style of writing showing good literary taste.

In 1885 there was held in New Orleans a National Cotton Exposition. Colonel Brackett was delegate at large from Iowa, had charge of an exhibit of Iowa fruits, and wrote to the meeting of the Horticultural Society when it was in session at Atlantic, Iowa, that Iowa had taken the gold medal and premium of $\$ 200$ for the largest and best collection of fruit from the states north of Missouri east to the Atlantic, besides other medals and premiums. ${ }^{18}$ The society passed resolutions thanking Colonel Brackett for labors which brought honor to the state.

At the January, 1886, meeting of the society, held in Des Moines, Colonel Brackett made a full report of the labors of himself and his helpers in' collecting the exhibits from over the state, of their arranging them at New Orleans, and of the successful result. At that meeting a committee consisting of C. L. Watrous, Silas Wilson, J. L. Budd, and G. B. Brackett was appointed to superintend the finishing and furnishing of the new rooms in the Capitol that had been assigned to the society. ${ }^{19}$ J. L. Budd declined to longer serve as secretary and G. B. Brackett, in his absence, was elected to that position and served for the year 1886. In his report to the society at its meeting at Charles City in January, 1887, he stated the society's rooms in the new Capitol were finished, but the necessary furniture was not secured, that the Executive Council claimed they had no funds available for that purpose.

17Ibid., 1880, p. 80.

18Ibid., 1884, p. 251.

19Ibid., 1885, p. 215. 
At the January, 1888, -meeting held in Des Moines, and for the first time in the Horticultural Rooms of the Capitol, Colonel Brackett was chosen librarian and custodian, a position he retained for four years. At this meeting he made an extended report as delegate from the society to the American Pomological Society held in Boston in September, 1887. There he met many noted pomologists and listened to discussions of value along scientific and experimental lines, which he described. ${ }^{20}$

Colonel Brackett continued to attend the meetings of the State Horticultural Society and to contribute papers of unusual value to fruit growers, indeed the variety of subjects he treated is almost marvelous, and the keenness of his observations of nature's laws. In 1891 he consented to again serve as secretary of the society which he did for that year. He had been for several years a member of the committee in charge of experimental stations of the State Horticultural Society and in 1890, when the number of stations had grown to nineteen, he was made general manager of those stations and retained that position for the following six years, or during 1895. He made reports to the society at different times. At the meeting in December, 1895, he reported having recently visited the then fifteen stations and gave information about their work and results. ${ }^{21}$

Before this time Colonel Brackett's reputation as a pomologist had so far exceeded his state that he was more and more called into national activities. In 1893 he represented the pomological division of the United States Department of Agriculture at the Chicago Exposition of that year. ${ }^{22} \mathrm{He}$ was not at the annual meeting of the Iowa State Horticultural Society of 1896, which was held at Des Moines December 8 to 11 , but sent them the following letter:

U. S. Department of Agriculture

Division of Pomology

Washington, D. C., December 7, 1896.

To the members of the Iowa State Horticultural Society,

Greetings

It is with sincere regret that circumstances are such as to preclude the possibility of meeting with you at this, our annual convention. But though absent in body I am with you in spirit. Having been a member of this noble society from its inception, and having become so identified

20 Ibid., 1887 , pp. 157-65.
21 Ibid., 1895 , pp. $91-99$.

22Who's Who in $\Delta$ mer., Vol. VII (1912-13), p. 224. 
with it in all its interests and efforts to promote the cause of horticulture, it would indeed be strange if I should be unmindful of you on memorable occasions. Hoping that you will all use your best talent and work in perfect harmong for the elevation and promotion of horticulture,

I am with sincere regards, yours fraternally,

G. B. BRACKetт, ${ }^{23}$

At about this time he seems to have become permanently attached to the Division of Pomology, United States Department of Agriculture. When James Wilson became secretary of agriculture in 1897 he made his fellow Iowan chief of that division. $^{23 a}$ When the Iowa State Horticultural Society was in session at Des Moines in December, 1898, it received from him the following letter:

\section{U. S. DEPARTMENT OF AGRICULTURE, DIVISION OF POMOLOGY, WASHINGTON, D. C., DECEMBER 10, 1898.}

Hon. George Van Houten, Secretary Iowa Horticultural Society:

Dear Sir: It is now expected that the Division of Pomology of the Department of Agriculture will make an exhibit of fresh fruits at the Paris exposition on 1900. It will endeavor to have the fruit in place on the opening day and continue the exhibit until the close of the exposition. In order to do this, it will be necessary to collect specimens of fruit of the crop of 1899 and place it in cold storage until time of shipment-about January 1, 1900. If your society wishes to co-operate with this division by contributing Iowa fruits to the display, it will be advisable to make such arrangements as may be necessary at your meeting for collecting the fruit and caring for the same. A committee should be appointed and instructed to act ad interim for the society.

It will involve a considerable expense, for which the society should make ample appropriation. The space allotted is so limited that no state will be allowed room for a separate exhibit, but each state will be credited with the fruit contributed.

Definite information and instruction will be given in due time. Please lay this matter before your society, and advise me at an early day of its action. Yours truly,

\section{G. B. Brackett. 24}

Colonel Brackett served as horticultural expert of the United States Commission to the Paris Exposition of 1900, and also served there as a member of jury, class 45 , group viii. ${ }^{25}$ Concerning this the Fort Madison Democrat had this to say:

23 Report Ia. State Hort. Soc., 1896, p. 124.

23a Biographical sketch in Hort. Report, loc. cit.

${ }^{24}$ Report Ia. State Hort. Soc., 1898, p. 58.

25 Who's Who in Amer., loc. cit. 


\section{AN OLD LEE COUNTY CITIZEN}

Has Entire Charge of the Horticultural Exhibit at the Big Paris

Exposition

Colonel Geo. B. Brackett, for many years one of Lee County's most prominent citizens, his home being in Denmark, but of late years resident at Washington, D. C., has been given entire charge of the whole horticultural exhibit of the United States at the Paris Exposition. The Washington Star in an article on the subject says:

"The fruit canning industry of the United States, so extensive and important, not alone in this country, but in the market of the entire world, is to receive a share of attention in the American exhibit at the Paris Exposition commensurate, as far as space will allow, with its commercially exalted position. The material and samples to be used in the display have already been shipped to the French eapital and will be in position, it is expected, when the big fair is thrown open April 15.

"The work of collecting and managing the preliminaries of the exhibit of the canned fruits and vegetables was accomplished by Colonel G. B. Brackett, pomologist of the department of agriculture, and honorary expert in horticulture on the United States Commission of the Paris Exposition. Captain Brackett was assisted by Mr. William A. Taylor of his bureau. The exhibit will include, aside from the commercial features of fruit and vegetables growing, a rare collection of ornamental plants and flowers, as well as samples of American landscape gardening, in model and actuality. The main portion of the exhibit will be installed in the palace of horticulture, while the remainder will be in the open air in the form of growing plants and specimens of landseape work. Colonel Brackett has charge of the entire horticultural exhibit of the United States." 20

Colonel Brackett was for two years secretary of the American Pomological Society, a distinction further indicating his high standing in his profession. ${ }^{27}$

At its meeting in Des Moines in December, 1901, the Iowa State Horticultural Society received a visit from Colonel Brackett. President M. J. Wragg, in introducing him, spoke as follows:

Iowa has always been proud of the record she has made, not only in horticulture but in other branches of pursuit, and I know of no one man that is more responsible for her success in horticulture than the man I am about to mention. We are honored this afternoon by having with us the United States Pomologist-one of the oldest members of this society-one of its secretaries way back in its infancy, and one who has done as much as any one man to bring it to its present con-

${ }^{26} \mathrm{Ft}$. Madison Democrat, March 16, 1900, p. 3. In the Newspaper Div, of the Hist., Memo. and Art Dept. of Ia.

27Who's Who in Amer., loc. cit. 
dition. I now have the pleasure of presenting Colonel Brackett, of Washington, D. C.

Colonel Brackett responded in part as follows:

This is rather unexpected and to undertake to make a speech now I believe is asking too much from me. I have just barely got my breath, coming from the depot. .... I was within 150 miles of you on special business, and I thought I couldn't afford to miss the opportunity to once more look into the faces of the old comrades and members of this society, therefore I took the train this morning and have just come directly from the east-side depot. I notice there are many that are not here-those who were the organizers of this society when I first met with them, away back in the seventies. . . . . There is a new element introduced into the society, and I hope these members are as earnest as the members were in the past. I know from the reports I get that the society shows as great an interest as ever, and I do not know of any society in the states that is doing more for horticulture than the Iowa State Horticultural Society, and while there are problems you will have to work out, which are interesting, the most important work for you to carry out is to investigate the different varieties and propagate such as are adapted to this climate. I hope to meet you all during the short time $\mathrm{I}$ am here. .... , and with this I beg to be excused. ${ }^{28}$

Colonel Brackett remained with the Division of Pomology, Department of Agriculture, Washington, the years following, most of the time being chief of the division. ${ }^{29}$ His death occurred at Washington, D. C., August 2, 1915, and burial was in Arlington Cemetery by the Loyal Legion of which he was a member. ${ }^{30}$ It is appropriate in closing to quote from a sketch in the 1915 Report of the Iowa State Horticultural Society, supposedly written by Wesley Greene, who was then secretary of the society. Following are excerpts from it. Speaking of Colonel Brackett it says:

His fame as an authority on fruits and their culture was world-wide. Specimens were sent to him from every section of the country for identification and he could usually give the name and history of the variety and its value for that locality. He had an artistic skill in molding wax fruits that few could equal. He made a collection of wax models of Iowa fruits for the exhibit at the Centennial Exposition at Philadelphia in 1876, which is still in the rooms of the society. He also supplied the Department of Agriculture with a large collection of wax models of fruits while he was at the head of the division of pomology.

28Report Ia. State Hort. Soc., 1901, pp. 143-44.

${ }^{29 S e e} U$. S. Official Register, 1909 , p. $71 ; 1911$, p. $69 ; 1913,180 ; 1915,185$; Who's Who in Am., loc. cit.

30Biographical sketch in Hort. Report, loc. cit, 
He knew fruit better than any man in the country from long study of varietal differences in form and color as modified by environment.

He was a companionable man, easily approached and would sit for hours and talk familiarly with inquirers about how to plant and prune trees and plants and to spray to protect them from their enemies. He had a fund of information to impart on their subjects from long years of experience with plants.

Colonel Brackett was not aggressive in his manner, but modest and very conservative in his statements. He made friends easily and held them by his kindly disposition and sincerity of purpose. No one knew him but to love him for his manly virtues. The world is better for his having lived in it for his life ministered to the poetic and æsthetic sensibilities of men.

\section{TO PRESERVE TOMATOES}

Messrs. Editors: As I am very fond of tomatoes, and have a way of preserving them to use, when the season for them is over, a way which I have never seen proposed, although others may have heard of it, I have concluded to send it if you think proper.

Dip the ripe tomatoes in scalding water, peel them and divide them into two, or if very thick through, three slices. Lay them on plates and put them into the oven after the bread is drawn. If a good oven [Dutch oven, or out oven], by the time it is cool, or in forty-eight hours, they will be perfectly dried. Put them into paper bags and keep them in a dry place. When wanted for use dip them into cool water and lay them on a dish to swell, and in a mince or stew they are almost equal to the fresh fruit. If you wish to make tomato sauce, add a little water to cook them in. They are very good to eat out of hand in the dry state.

Brooklin, May 9, 1844.

-Bloomington (Muscatine) Herald, August 23, 1844. (In the Newspaper Division of the Historical, Memorial and Art Department of Iowa.) 
Copyright of Annals of Iowa is the property of State of Iowa, by \& through the State Historical Society of Iowa and its content may not be copied or emailed to multiple sites or posted to a listserv without the copyright holder's express written permission. However, users may print, download, or email articles for individual use. 